\title{
NOTES ON THE FULGORIDAE WITH SOME NEW SPECIES.
}

\author{
By E. D. BALL, \\ University, Tucson, Arizona.
}

The large and showy representatives of the sub family Fulgorinæ are largely tropical, only a few of the smaller and more somber forms appearing along the southern boundary of the United States. Owing to the fragmentary character of our knowledge of the tropical forms it has been difficult to correctly place even the few we have. In a recent survey the following additions and corrections appeared to be warranted.

Calyptoproctus marmoratus Spin. 1839 (=Crepusia glauca Metc. 1923). Spinola and Stal describe Calyptroproctus as having the fifth dorsal segment of the female abdomen as long as the three preceding segments and tricarinate. Metcalf, in his key, gives ninth abdominal segment elongate quinquecarinate for Calyptroproctus Spin. and ninth abdominal segment not elongate, not quinquecarinate for Crepusia Stal. (italics mine). He must have misinterpreted the description and overlooked the fact that this character is only present in the females and examined only males of his Crepusia glauca, of which he reported 12 males and only one female. The females of this Arizona species have the elongate tricarinate segment and answer in every way to the description of marmoratus and to Dozier's figure of the Mississippi example.

This species is now definitely known from Mississippi, Brownsville, Texas, and from a number of places in the southern half of Arizona.

Crepusia is apparently one of the many genera proposed by Stal in his Hemiptera Africana keys that were never described or to which no species was referred. The characters given in his "Key to the American Fulgorid Genera" 
are inconsistent with those given previously. It seems best therefore to fix glauca Metc. as the type of Crepusia Stal. which will make it a synonym of Calyptoproctus if marmorata is correctly referred to Calyptoproctus as represented by elegans L \& S its type.

Poblicia fuliginosa Oliv (1791) (=missella Stal (1864) (=thanatophana Kirk (1907). This large dark species has a line on the vertex, the transverse veinlets towards the apex of the elytra as well as scattered small spots, creamy white. It varies in shades of brown or black but the posterior two-thirds of the abdomen above is always scarlet red with four lines of black dots, which agrees with the various descriptions. It is found from North Carolina, Ohio, Kansas and Southern Arizona, south to Georgia, Texas and Mexico.

\section{Cyrpoptus vanduzeei Ball n. sp.}

Similar to nebeculosus but smaller and darker. The smallest darkest species in the genus. Dark brown, vertex creamy, with a broad, medium black stripe. Length (with elytra) $10 \mathrm{~mm}$.

Form of metcalfi, smaller with a relatively shorter, thinner, more depressed and foliaceous vertex. Vertex evenly rounding, little if any longer than pronotum, half longer on middle than against eyes. Pronotum with a definite median carina and traces of lateral ones behind the eyes. Mesonotum with three broad carinae indicated. Elytra with the lateral margins but slightly sinuated, the apical margin scarcely oblique.

Color dark brown mottled, the vertex and apex of mesonotum creamy with a broad black median stripe throughout. Elytra with the basal two-thirds dark, the apical third subhyaline, heavily brown flecked in more or less concentric rows. Underwing hyaline with smoky veins, the basal third pale yellow, the angle of the folded area with a small dark cloud, abdomen pale yellow above. Face soiled tawny, the lower part of clypus and coxae dark brown; venter finely irrorate.

Holotype $q$, one $q$ and two male paratypes Baboquivari 
Mountains, April 11, 1932. Allotype ô Santa Cruz River April 22, 1932, and one paratype $\&$ Tucson, April 27, 1930. All taken in Arizona by the writer from bunches of mesquite grass (Muhlenbergia porteri) growing under spiny shrubs. Named in honor of E. P. Van Duzee whose foundation work on the Fulgoridae of Temperate North America will long endure.

Cyrpoptus metcalfi Ball n. sp.

Smaller and narrower than belfragei, much paler. Pale testaceous, the subhyaline elytra allowing the orange and black of the wings to show through. Length (with elytra) 12-14 $\mathrm{mm}$.; expanse $26 \mathrm{~mm}$.

Vertex roundingly produced, the margin thick and the surface depressed, longer than the pronotum, twice as long on middle as against eyes, front as seen from side strongly concave, the upper part and vertex compressed foliaceous, little if any thicker than the margin.

Color, uniform pale cinnamon with a tawny tinge, no definite spots or markings, face and below pale creamy, occasionally finely irrorate with scarlet above. Vertex creamy, base of pronotum washed with brown omitting a median carina. Elytra subhyaline, under wings hyaline with orange nervures, the basal third reddish orange, the apex of the fold black, abdomen yellow above.

Holotype $\circ$, allotype $\delta$ and 14 paratypes, August 25, 1929, Yuma, Arizona. These were taken by the writer sweeping on arrowweed (Pluchea sericea) and mesquite in the Colorado River bottom. Named in honor of Dr. Z. P. Metcalf who has recently published upon the Fulgoridae of the Eastern United States. From nebeculosus this species can be separated by its smaller, narrower form, lack of dark spotting and the convex ventral surface of the male plates while in that species they are furrowed. It is smaller and has a longer head than suavis, from Mexico.

Ormenis quanta Ball n. sp.

Form and size of pallidacosta nearly, broader, with angularly produced front. Green. Length $\$ 14 \mathrm{~mm}$. of $12 \mathrm{~mm}$. Width of $q$ elytra at apex $8 \mathrm{~mm}$. 
Front narrow, extending forward and downwards threefourths its length, then abruptly retreating in line with the clypeus forming a right or slightly obtuse angle, lateral margins foliaceous and broadening to the antennae, a median carina extending to the angle, mesonotum large, convex, polished, faintly tricarinate. Elytra as in pallidacosta expanding apically where they are truncate with the inner angle acute and the outer (costal) very slightly rounding. Two rows of transverse veinlets slightly more definite in pallidacosta. Color pale green, probably deep green in life, with the front and clypeus paler, shading to straw.

Holotype $\&$ allotype $\hat{\sigma}$ and one paratype Iguala Gr. and three paratype males Cuernavaca, all taken in Mexico in September 1898 by O. W. Barrett. This species would run to the genus Lechara Stal in Melechar's key on the angled front, but this group is from the Celebes and quite distinct in other structures. This species seems to be a typical Ormenis, near pallidacosta and is so placed. It is easily separated by the green, rather than the blue-green color of that species and by the angled front.

\section{Ormenis yumana Ball n. sp.}

Small, powdery green or slaty white, with a smoky tip, resembling leucophaea in the slender form but with two definite transverse lines. Length $\& 8 \mathrm{~mm}$. of $8 \mathrm{~mm}$., width of elytra $3 \mathrm{~mm}$.

Front broader than long, the margins rounding, disc flat with a very feeble median carina and traces of one on the vertex margin; elytra more than twice longer than wide, the margins parallel, the apex slightly obliquely truncate with the angles equally rounding. Two distinct lines of transverse nervures, with only about 10 full length cells between them instead of very indistinct with about 14 cells in saucia and only one line in leucophaea.

Color, pale green becoming smoky posteriorly with scarcely a trace of blue-green as in relicta, or almost entirely slaty with the nervures green, or becoming white on 
the darker apex. The costal margin is paler becoming almost white in the slaty examples.

Holotype $q$, allotype $\hat{\sigma}$, November 2, 1929, a pair of paratypes August 25, 1929, two males March 16, 1930, two pairs March 29, 1932, two females June 9, 1931, all from Yuma, Arizona, and one female, Calixico, California, June 10, 1931. All collected by the writer. The specimens taken in March were all slaty. Those taken in the summer, green.

Acanalonia servillei Spinola (=Acanalonia latifrons Walk)

There is certainly but a single large blunt-headed species of this genus occurring in the United States. The definite median carinae from vertex to mesonotum, renders it strikingly distinct in the group. A. servillei was described from Philadelphia, while latifrons was from New Orleans. The writer has collected this species abundantly on the grounds of Swarthmore College near Philadelphia, and again in still greater abundance in Florida. He has a large number of examples from Hayti and has examined material from Pennsylvania south to South America in different collections and feels certain that there is but one species involved.

\section{Acanalonia saltonia Ball n. sp.}

Form of clypeata nearly, much larger, with the front rather than the clypeus inflated. Long, narrow, pale green with an obtusely conical head. Length os $9 \mathrm{~mm}$., width of elytra $4 \mathrm{~mm}$.

Vertex resembling clypeata, more definitely angled than in virescens, flat on disc. Elytra long, narrow, parallel margined and almost truncate at apex, much longer than in virescens. Face sloping, the front inclined to be inflated, the clypeus broader above than in clypeata and less inflated. Pale powdery green in life, fading to pale straw.

Holotype $\hat{\sigma}$ and two paratype males taken by the writer at Imperial, California, June 18, 1909.

Acanalonia virescens Stal. A male that agrees with Mexican material of this species was taken by the writer at Marco, Florida, May 15, 1928. 
Acanalonia mollicula V. D. The writer has collected this blue-green species in Southwestern Utah, Southeastern Nevada and Northwestern Arizona, in addition to Mojave and Jacumba, California.

Acanalonia concinnula Fowl. The writer took a male of this species at Venice, Florida, July 27, 1927. This example agrees with China's recent drawings and has the brown stripe on the suture. It appears to differ from fasciata in a number of characters.

\section{Acanalonia planata Ball n. sp.}

Resembling concinnula but with a longer, flatter carinate vertex and almost semicircular elytra. Pale green. Length ô $6 \mathrm{~mm}$.; width of elytra $3 \mathrm{~mm}$.

Vertex broad, flat, horizontal, longer than pronotum, joining the front in a right angle, the margin with a definite carina, anterior margin rounding, posterior margin concave, parallel. Front upright, the lateral margins parallel, clypeus sloping back. Elytra hemispherical entirely, rather finely, reticulate, longitudinal nervures with few branches.

Holotype $\hat{o}$ and a paratype $\hat{o}$, Brownsville, Texas, July. This is a larger species with a much longer and more produced head than laticosta from the same region. 

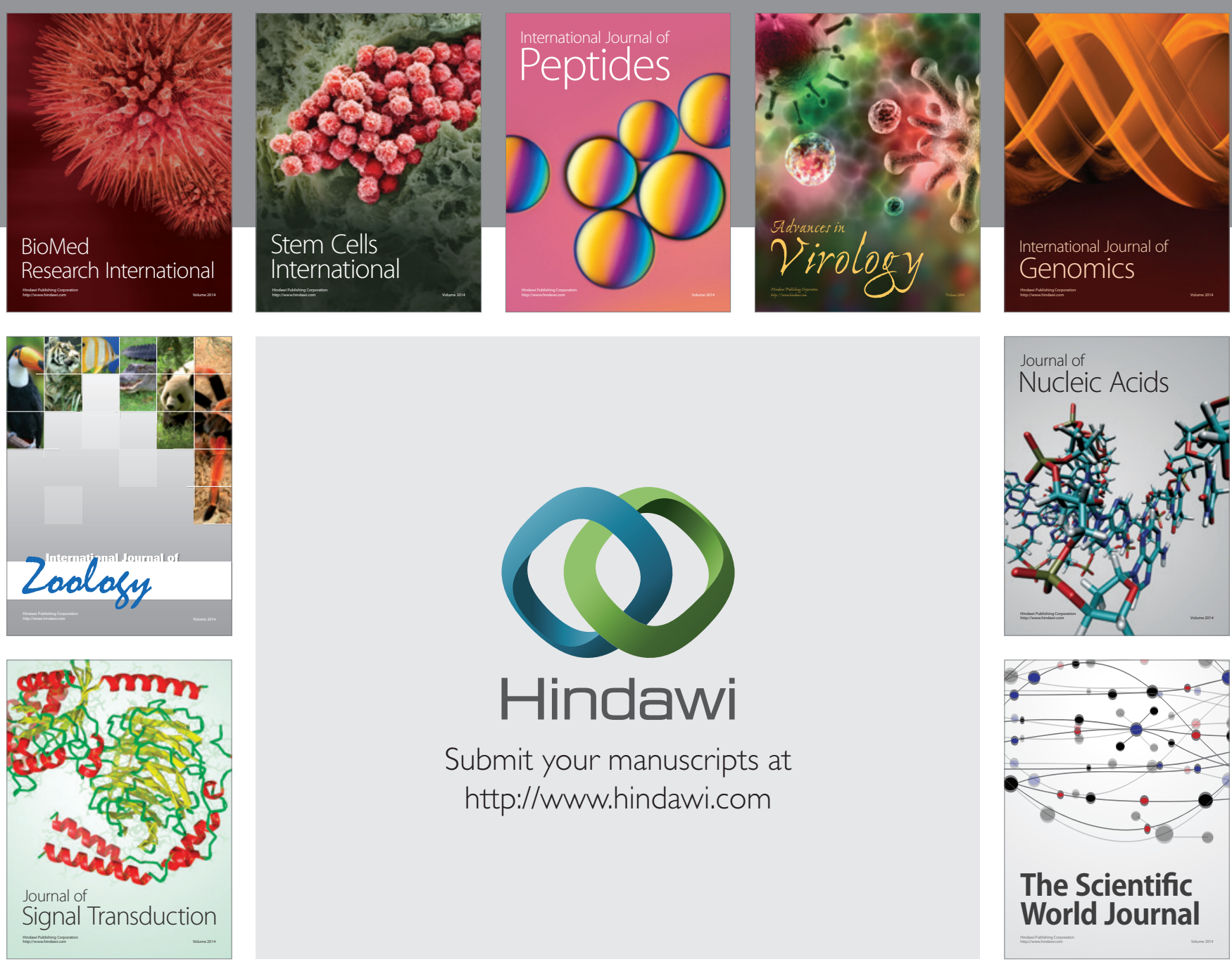

Submit your manuscripts at

http://www.hindawi.com
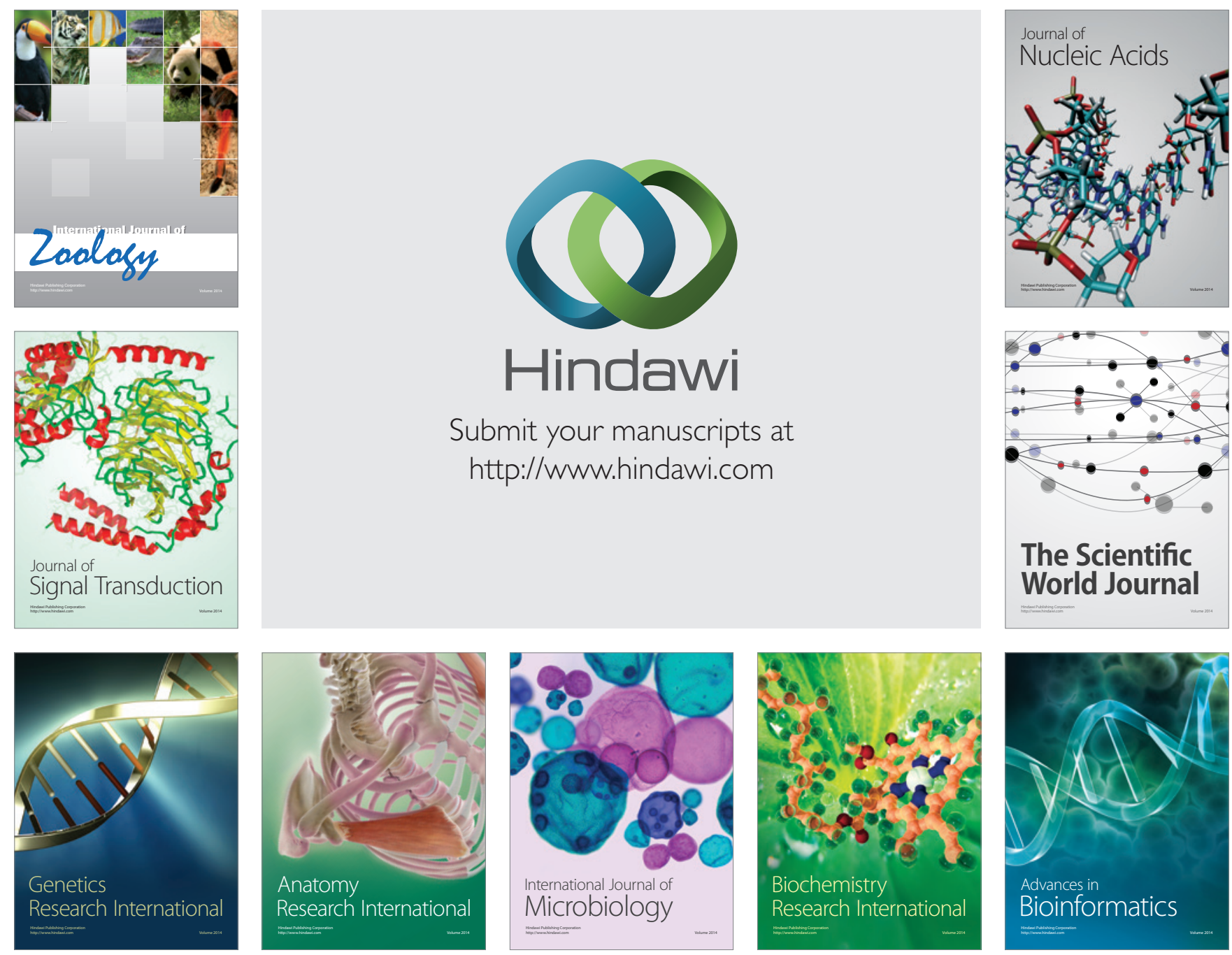

The Scientific World Journal
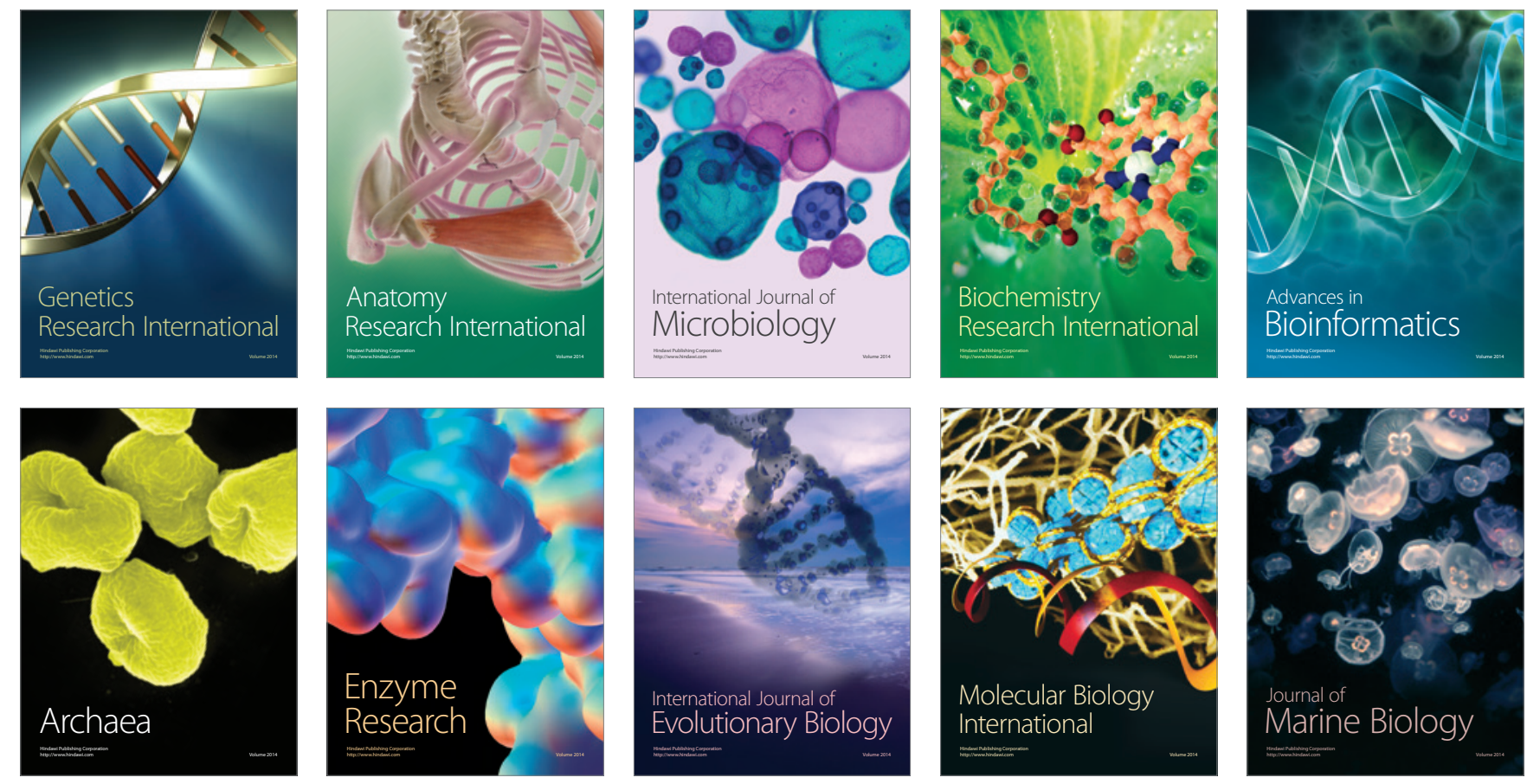